\title{
Teaching Aircraft Design: A Case Study on an Alternative Engineering Undergraduate Capstone Final Year Project
}

\author{
Andrea Cartile ${ }^{a *}$, Catharine C. Marsden ${ }^{b *}$, Yong Zeng $^{a *}$, and Brandiff Caron ${ }^{b *}$ \\ ${ }^{a}$ Concordia Institute for Information Systems Engineering, Faculty of Engineering and Computer Science, Concordia \\ University \\ ${ }^{\mathrm{b}}$ Centre for Engineering in Society, Faculty of Engineering and Computer Science, Concordia University \\ * Corresponding Authors: andrea.cartile@mail.concordia.ca, c.marsden@concordia.ca, zeng@ciise.concordia.ca, \\ brandiff.caron@concordia.ca
}

\begin{abstract}
The effectiveness of aerospace design engineering education has received a great deal of anecdotal feedback from its stakeholders. The aerospace industry, the Canadian government, the University, and the enrolled engineering students have expressed customer needs and expectations of design engineering training. While numerous curriculum reform initiatives have been developed and implemented, their impact has not yet been studied quantitatively. This paper proposes to use a theoretical model on design creativity, the statistical $Q$ methodology, and an aerospace undergraduate capstone team case study to develop a tool for the quantitative evaluation for the effectiveness of aerospace design engineering education.
\end{abstract}

Keywords: Aerospace design education, stakeholders, capstone, design creativity model, Q methodology

\section{INTRODUCTION}

The teaching of design skills as part of the undergraduate engineering curriculum has received a lot of interest over the last decade. 'Design engineering' has emerged as a term to describe an engineering discipline that combines technical competencies, innovation, teamwork, leadership, communication, resource management, and customer and business needs analyses to develop solutions for society [1]. The design engineer usually works as part of a multi-disciplinary team to produce conceptual and detailed designs for a functional product that meets a complex set of requirements and constraints. One of the most challenging environments for the design engineer is the aerospace industry and its associated high-performance, multi-disciplinary, and complex system-of-systems product. Design engineering skills, paired with a thorough understanding of its associated methodologies, are highly relevant for graduating engineers hoping to pursue careers in this industry. The research question posed in this paper is "How should we design the undergraduate aerospace curriculum to more effectively teach design engineering and prepare students for a career as a design engineer in the aerospace sector?"

In this paper, the authors address the research question in three steps. First, using a well-known design engineering approach, the study begins with a Triple Helix universityindustry-government and student stakeholder analysis [2], or a 'voice of the customer' review. Subsequently, a curriculum reform, currently in its first two years of implementation, is presented in the context of a novel theoretical model of design creativity. Anecdotal conclusions are drawn based on observations made during the first year of the new curriculum implementation, and both qualitative and quantitative methods are proposed for ongoing evaluation of the program over the next four years.

\section{THE VOICE OF THE CUSTOMER}

The first two stakeholders considered are the aerospace industry and the Canadian economy. Canada's aerospace industry is currently experiencing challenges in their capacity to replace retiring engineering personnel. The age and experience gap between the retiring population and the newly hired engineers has resulted in a deficit of skill and experience [3], eliciting an increased interest in the educational background of the engineering graduates that are being recruited to fill these openings. Anecdotal feedback from industry on the strengths and weaknesses of today's aerospace engineering education programs has been very well documented. Published lists of desired attributes and skills for new engineering graduates 
continuously highlight the need for curriculum reform [4]. Dissatisfaction with the student readiness level upon finishing a degree has been a predominant theme among surveyed companies, particularly with respect to training in design [5] [6]. There is a demand for technical specialization at both high and detailed levels, software familiarity, and proficiency in business processes and professional skills, such as team work, self-sufficiency, and written and oral communication [1]. This need for aptitude agility and task flexibility is common to both small-tomedium-sized enterprises (SMEs), which make up $70 \%$ of Canadian private employment [7], and to larger original equipment manufacturers (OEMs).

While engineering undergraduate students can be considered both customers and products of the educational process [8], they are certainly a primary stakeholder. A study of final year undergraduate engineering students found over $90 \%$ of students expected to continue into industrial careers [9], and it can be assumed that, upon registering for a university degree, they expect to receive training that will prepare them to be a job-ready, marketable, and most importantly, hirable candidates [10].

Another important stakeholder is the university itself. Universities compete for the most promising students, and it is in their interests to offer programs that students believe will lead to successful careers. Specialized programs and curriculum reform require time, money, personnel and, often, a cultural change from within the university [11] [12]. Feedback and continuous improvement systems are inconsistent from one institution to another and, due to pressure on faculty to produce research, curriculum reform and teaching-related initiatives are often not given priority.

\section{ENGINEERING DESIGN CURRICULUM TO ADDRESS THE VOICE OF THE CUSTOMER?}

The traditional structure for the engineering course curriculum is a highly regimented, chalk-and-talk, single solution-based set of first year courses, leading to a slightly less structured $2^{\text {nd }}$ and $3^{\text {rd }}$ year featuring semester-long projects with multiple solutions, and finally culminating in a year-long capstone design project structured on the build, test, present, report format [13]. Students execute each phase individually or in small groups, and are rarely presented with the opportunity for interdisciplinary work [14]. While the progression seems to follow a logical trajectory, students are only trusted with a full-scale design in their final year, thereby not giving them the chance to learn from their mistakes by trying again on either a subsequent iteration or on another project entirely. This sequence poses severe limitations on the opportunity for the systematic application of varying design methodologies, and stifles any possibility of mentorship by senior students.

Several universities have acknowledged these shortcomings, and have redesigned their curriculum to better suit the needs of their customers [15] [16]. The Massachusetts Institute of Technology has developed and implemented the conceive-design-implement-operate (CDIO) industry-based design methodology, and has explored the benefits of problem-based learning within the context of their Aeronautics and Astronautics course curriculum [17]. California Polytechnic State University has incorporated a full $2^{\text {nd }}$ year aircraft design course, which uses a 'just-in-time' lecture style and $4^{\text {th }}$ year students to provide mentorship for the learning process. This approach addresses the importance of peer mentorship, and results support the theory that "learn-bydoing" is an effective tool to incite motivation for courses and projects alike [18]. Queens University in Ontario, Canada has addressed another issue in the design education system: the infrastructure. They have situated multiple engineering departments in the same building and incorporated multi-purpose laboratories with toolbox-style interchangeable equipment. There is a strong emphasis on classroom flexibility with movable chairs, tables, desks and white boards. Collaboration is encouraged with ample seats and tables in open spaces, and the availability of many closed meeting rooms that can be reserved by students collaborating on design projects [19].

The NSERC Chair in Aerospace Design Engineering (NCADE) at Concordia University is taking initiatives in curriculum reform as part of a new undergraduate degree in Aerospace Engineering. Following extensive research and industry stakeholder analysis [20], the approach encompasses a variety of different learning opportunities with an emphasis on experiential learning through industry apprenticeships, "hands-on" laboratory experiences, and a design-focused capstone project that strives to replicate an industrial design environment. The final year capstone project is a single team of over 30 students from departments across the engineering faculty, and is structured on the principles of problem-based, case-based, and inquiry based learning [21]. Students are provided with a Request for Proposal for a clean-sheet aircraft design, which they must bring to a Preliminary Design maturity over the 8 months of their final year. Subjected to weekly design reviews that are open to industry guests, all team members must present their individual and team work on a regular basis. Students are expected to self-manage, selfteach, and meet expectations with respect to engineering technical expertise and professional skills development. The resulting aircraft design maturity is determined by the ability, motivation and determination of the team, and progress is monitored by the capstone supervisor at each design review [22]. 


\section{HOW CAN WE MEASURE THE EFFECTIVENESS OF PROPOSED SOLUTIONS?}

Much of the literature on final year design project reform reports on customer satisfaction anecdotally. While this type of evaluation is a useful starting point for further study, it does not yield a comparable basis for the evaluation of the effectiveness of competing solutions. Concordia University's NCADE research group has launched an initiative to develop quantitative evaluation tools for the effectiveness of teaching and learning using qualitative data derived from the implicated stakeholders. The proposed process is divided into three stages: categorization using the mental capacity model proposed by Drs. Thanh An Nguyen and Yong Zeng [23], statistical analysis using the Q methodology [24], and a comparative evaluation between anecdotal accounts and statistical variability for verification of method viability.

The mental capacity model proposed by Drs. Thanh An Nguyen and Yong Zeng is used to classify student behaviour based on three aspects; knowledge, skill, and affect. Knowledge is described as the availability of working memory regarding a known existence of information and where it can be found, skill is the ability to apply this knowledge successfully through thinking strategies or reasoning methods, and affect is a person's mental state associated with emotion [23]. The mental capacity model is presented in Figure 1.

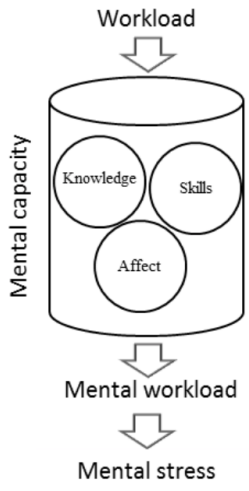

Fig. 1: A theoretical model of design creativity by Drs. Thanh An Nguyen and Yong Zeng [23]

The mental capacity is studied within the context of the perceived input workload and output mental workload resulting in mental stress, which has a direct effect on creativity. Creativity has been defined as a novel and useful idea or solution [25], perhaps more commonly interpreted as innovation in the context of aerospace engineering.
Figure 2 displays the relationship between mental stress and creativity.

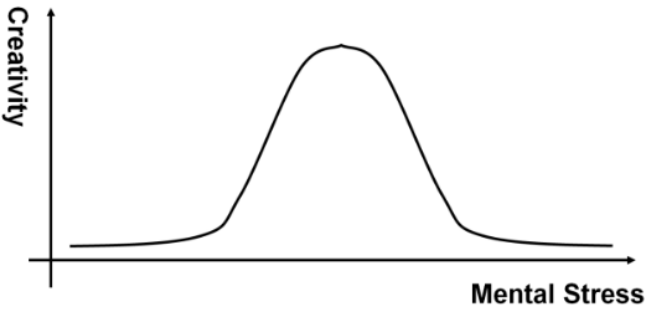

Fig. 2: Relationship between creativity and mental stress [23]

Margaret A. Boden categorizes creativity in two senses: psychological creativity, where an idea is novel to the person who has it, and historical creativity, which describes an idea that has never been thought of before by anyone [25]. Psychological creativity is notably important within the education environment, as it suggests learning, while historical creativity can be associated with innovation and industrial success in a competitive market.

Language has been chosen as the mechanism for evaluating creativity in the NCADE project environment [26]. Tools that include surveys, writing exercises, recorded presentations, and design books will be used to track changes in knowledge, skill and affect from start to finish of the Capstone project. The preliminary findings of patterns and trends for both student progression at an individual level and between students at any given point will form the basis for the development of a Q methodology questionnaire.

The $\mathrm{Q}$ methodology is a process that eliminates the subjectivity of anecdotal reporting through imposed statistical variability [24]. A questionnaire must first cover a full range of possible impressions on a specific subject. Subjects are asked to answer these questions, and then categorize them into a spectrum of relative agreement and disagreement. The suggested categorization rubric, or Symmetrical Q-grid, can be seen in Figure 3.

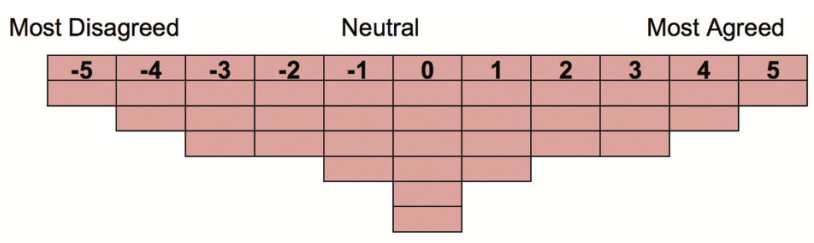

Fig. 3: Example of a symmetrical Q-grid [24]

The necessity for the full coverage of the opinion spectrum on a topic becomes apparent in the Q-grid, as it allows the participant to generate a standard normalized 
data distribution, all within the relative context of the individual's experience. The distribution of the question numbers within this chart can then be statistically analyzed, exposing valuable multivariate information on a student's experience.

A pilot project version of the NCADE Capstone project has recently ended, and some first observations have been recorded. Contrary to many literary findings, preliminary anecdotal observations of the first iteration of this 30 person style of capstone project have reflected positively on the development of engineering technical and professional skills. $70 \%$ of students participated in one-onone exit interviews, conducted by the researcher and a future undergraduate NCADE capstone participant [27]. $100 \%$ of the exit interview participants reported having had no prior aircraft design experience, yet exhibited notable technical expertise upon course completion. Professional skills, such as writing and presentations, remarkably improved over the course of the weekly design reviews, and the experience gained was unanimously reported as having been highly beneficial in the participants' selfdevelopment and future careers. The challenge of having to work and communicate effectively within a group of 30 students was difficult, but thought by the participants to be reflective of industry in terms of experiences such as conflict resolution and effective organizational structure.

The next phase of this initiative will be to evaluate samples of written and verbal communication obtained throughout the 8-month pilot project. The data will be used to establish commonalities between students in the areas of technical and professional knowledge, skill and affect. The results will be used in the development of a Q methodology questionnaire, which will be implemented the following year. The statistical results are expected to yield quantifiable feedback on course effectiveness as seen by the student stakeholder, allowing for more effective curriculum development.

\section{CONCLUSION}

While preliminary results of the pilot NCADE capstone project look very promising, a 5-year plan has been proposed to encompass a full evaluation of the effectiveness of this educational strategy. The first two years will be spent taking qualitative data through surveystyle, video, audio, and written format, and analyzed under the Nguyen and Zeng theoretical model for design creativity. The second year is expected to include other Concordia University capstone groups as a benchmark, and expand beyond the aerospace sector in a comparative analysis. The qualitative data will be used to develop a $\mathrm{Q}$ methodology questionnaire, yielding a quantitative strategy for large group data capture. Should the comparison between the results of the Q methodologyderived data match anecdotal feedback with acceptable error, it is anticipated that this tool can then be extended to other Canadian and international engineering programs, along with industry and university stakeholders, for a full quantitative analysis of the effectiveness of teaching and learning strategies in the final Capstone year.

\section{Acknowledgements}

The authors would like to thank the NSERC Chair in Aerospace Design Engineering (NCADE) program and its affiliated industry sponsors.

\section{References}

[1] M. A. Robinson, P. R. Sparrow, C. Clegg and K. Birdi, "Design engineering competencies: future requirements and predicted changes in the forthcoming decade," Design Studies, vol. 26, no. 2, pp. 123-153, March 2005.

[2] Stanford University, "The Triple Helix concept," Stanford University, 2012. [Online]. Available: https://triplehelix.stanford.edu/3helix_concept. [Accessed March 2017].

[3] C4SE, "Engineering Labour Market in Canada: Projections to 2025," Engineers Canada, Milton, ON, 2015.

[4] R. M. Goff and J. P. Terpenny, "Engineering Design Education - Core Competencies," in Industrial and Manufacturing Systems Engineering Conference Proceedings and Posters, Nashville, Tennessee, 2012.

[5] E. May and D. S. Strong, "Is Engineering Education Delivering What Industry Requires?," in Proceedings of the Canadian Engineering Education Association, Toronto, 2006.

[6] S. Tan, C. Marsden and Y. Zeng, "Educating Aerospace Design Engineers: Perspectives from Design Creativity Theory," in Proc. 2016 Canadian Engineering Education Association (CEEA16) Conf., Halifax, 2016.

[7] Government of Canada, "Key Small Business Statistics June 2016," 6 June 2016. [Online]. Available: https://www.ic.gc.ca/eic/site/061.nsf/eng/03022.html. [Accessed March 2017].

[8] C. Obermiller, P. Fleenor and R. Peter, "Students as Customers or Products: Perceptions and Preferences of Faculty and Students," Marketing Education Review, vol. 15, no. 2, pp. 27-36, 2005.

[9] Ontario Society of Professional Engineers, "Crisis in Ontario's Engineering Labour Market: Underemployment Among Ontario's Engineering-Degree Holders," Ontario Society of Professional Engineers, Toronto, 2015.

[10] M. Tomlinson, "'The degree is not enough': students' perceptions of the role of higher education credentials for graduate work and employability," British Journal of Sociology of Education, vol. 29, no. 1, pp. 49-61, 2008. 
[11] J. Walkington, "A process for curriculum change in engineering education," European Journal of Engineering Education, vol. 27, no. 2, pp. 133-148, 2002.

[12] C. L. Manns and J. G. March, "Financial Adversity, Internal Competition, and Curriculum Change in a University," Administrative Science Quarterly, vol. 23, no. 4, pp. 541-552, 1978.

[13] J. E. Mills and D. F. Treagust, "Engineering Education - is problem-based or project-based learning the answer?," Australian Journal of Engineering Education, 2003.

[14] D. S. Strong and W. Stiver, "Engineering Design Competency: Perceived Barriers to Effective Engineering Design Education," in Proceedings of the Canadian Engineering Education Association, Kaninaskis, 2005.

[15] R. Perez, C. Marsden, T. Chalovich and W. Allan, "Implementing a Capstone Aircraft Design Project as an Integrated Multi-Disciplinary Development Experience," in 12th AIAA Aviation Technology, Integration, and Operations (ATIO) Conference and 14th AIAA/ISSMO Multidisciplinary Analysis and Optimization Conference, Indianapolis, Indiana, 2012.

[16] L. R. Jenkinson, G. J. Page and J. F. Marchman, "A model for international teaming in aircraft design education," Aircraft Design, vol. 3, no. 4, pp. 239-247, December 2000.

[17] D. R. Brodeur, P. W. Young and K. B. Blair, "ProblemBased Learning in Aerospace Engineering Education," in American Society for Engineering Education Annual Conference \& Exposition, 2002.

[18] D. W. Hall and R. M. Cummings, "The Happy Accidents of Teaching Aircraft Design," 45th AIAA Aerospace Sciences Meeting and Exhibit, 2007.

[19] D. S. Strong, Interviewee, Queen's University NSERC Chair in Design Engineering. [Interview]. 13 Feb 2017.

[20] N. I. Partners, Interviewee, NCADE Industry Partners Committee: "Voice of the Customer" Industry Needs Consultation. [Interview]. 24 July 2014.

[21] J. R. Savery, "Overview of Problem-based Learning: Definitions and Distinctions," Interdisciplinary Journal of Problem-Based Learning, vol. 1, no. 1, p. Article 3, 2006.

[22] C. Marsden, "NCADE Aircraft Capstone Design Project Course Outline," September 2016. [Online]. Available: https://moodle.concordia.ca/moodle/course/view.php?id= 91037. [Accessed 2016].

[23] T. A. Nguyen and Y. Zeng, "A theoretical model of design fixation," International Journal of Design Creativity and Innovation, 2016.

[24] J. Coogan and N. Herrington, "Q methodology: an overview," Research in Secondary Teacher Education, vol. 1, no. 2, pp. 24-28, October 2011.

[25] M. A. Boden, "Chapter 4: What is Creativity?," in Dimensions of Creativity, M. A. Boden, Ed., Cambridge, MIT Press, 1996, pp. 76-77.

[26] R. Cassidy, J. Bentley and A. Cundell, Interviewees, Center for Teaching and Learning and NCADE Research Strategy. [Interview]. 15 November 2016.
[27] 2.-2. NCADE Capstone Participants, Interviewee, Field Notes from First Iteration of NCADE Clean Sheet Aircraft Design Capstone. [Interview]. April 2017. 